\title{
Socialization of Prospective Physical Education Teachers: The Story of New Blood
}

\author{
CAMILLE P. O'BRYANT, MARY O'SULLIVAN \& JEANNE \\ RAUDENSKY
}

ABSTRACT There has been much criticism of how teachers are prepared to teach and physical education has not been immune from this criticism. Despite numerous efforts to improve the content and focus of teacher education programmes there is still a paucity of programme evaluation research on the efficacy of these teacher education programmes (Metzler \& Tjeerdsma, 1998). This paper reports on part of a yearlong investigation on the efficacy of a graduate physical education teacher education programme to prepare teachers. The focus of this aspect of the study was to identify what attracted graduate students to pursue a teaching career and what beliefs they held about physical education teachers and teaching. This was a qualitative case study and multiple data sources were gathered to address the research questions. The data sources included interviews, analyses of the students' autobiographical statements, and observations of their teaching, critical incidents from their teaching and peer responses to critical incidents. Findings indicate that this cohort of graduate students, many embarking on a major career change, was more committed to teaching and their love for teaching children than coaching. While their own success and love of sport was a factor in their career choice, their experiences in helping young people engage in and enjoy physical activity was more significant than their desire to gain a teaching credential. They believed their role as a physical education teacher was to be a physically active role model and help students appreciate the importance of physical activity, to contribute to the development of student self-esteem, especially those sometimes marginalized in physical education classes, and to plan and teach lessons that would motivate all students to participate in class. This work is grounded in the occupational socialization literature and the findings are discussed in terms of what we know about how to maximize the impact of teacher education programmes especially when students' beliefs may not be aligned with those of the programme.

\section{Introduction}

'Driven by a number of agenda-setting groups, such as the Holmes Group, the National Council for the Accreditation of Teachers (NCATE), and State legislatures, it is probably safe to say that every teacher education programme in this country [sic US] has undergone major changes in the past two decades' (Metzler \& Tjeerdsma, 1998, p. 468). There have also been criticisms of physical education teacher education programmes in the US during this period. For example, Physical Education Teacher Education (PETE) programmes have been criticized for their inadequate development of content knowledge (Rovegno, 1992); for having too great a focus on a technical orientation to teacher education with too little focus on an inquiry perspective (Kirk, 1986); and for having a lack of commitment to multi-culturalism, and appreciation for diversity both within the recruitment of students into PETE programmes and within the context of the delivery of physical education instruction (Fernandez-Balboa, 1997).

Several PETE programmes in the US are attempting to address these criticisms with 
significant innovations in the preparation of teachers. The PETE programme at University $\mathrm{X}$ is one example of such change efforts. Students who want to be physical education teachers now gain certification at the graduate level. Various changes in the academic structure and priorities at University $\mathrm{X}$ were at the core of a decision to move teacher certification to a master of education degree (M.Ed.). First, the general education requirements at the undergraduate level increased from $25 \%$ to $50 \%$ of the undergraduate requirement. This university mandate left less than 100 quarter-credit hours (of a 196 credit hour programme) for course work in a student's major. Further, the College of Education joined the Holmes Group now known as the Holmes Partnership and committed to graduate teacher education, school-based teacher preparation, a stronger content knowledge base and increased collaboration between schools and the university.

Despite national efforts to improve pre-service teacher education, there is little evidence presented to date that any of these changes are making teacher education more effective (Fullan et al., 1998; Metzler \& Tjeerdsma, 1998) as few if any programmes have engaged in systematic evaluation of their programmes. Planning for and moving to a graduate teacher education programme afforded this PETE faculty a unique opportunity to explore the efficacy of the new M.Ed. programme and its effectiveness in socializing graduate students into the profession. As such the faculty embarked on a yearlong study of the socialization of the pre-service teachers in the M.Ed. programme.

There are a variety of ways to describe the process of socialization into teaching (Lawson, 1983a; Stroot \& Williamson, 1993; Templin \& Schempp, 1989). Templin and Schempp (1989) engaged in the study of teacher socialization for the past two decades assuming a dialectic view of socialization and describing it as a dynamic process. A dialectic view of the processes of socialization views individuals as active agents in determining their behaviour and destiny (Templin \& Schempp, 1989). As such, teachers play an active role in the formulation of their beliefs, attitudes and behaviours toward teaching (Templin \& Schempp, 1989).

Two major theoretical models have been used to examine the socialization process of teachers: Fuller's Developmental Teacher Concerns Model (Fuller, 1969) and Occupational Socialization (Stroot \& Williamson, 1993). According to Stroot and Williamson (1993), the occupational socialization model is a more useful model to examine the process of socialization into teaching physical education. Three phases of socialization into teaching physical education have been identified within the occupational socialization model (Lawson, 1983a, 1983b; Templin \& Schempp, 1989). These phases are: (a) recruitment (anticipatory) socialization; (b) professional education (pre-service); (c) organizational socialization (entry into work).

Metzler \& Tjeerdsma (1998) proposed a development, research and improvement (DRI) model for PETE programme assessment. The model has three stages, 'development, research and decision-making' (p. 472). While we collected data that address various aspects of the DRI model, the focus of this paper is on the socialization aspect of a larger programme evaluation study. The research questions in the study are linked to the research phase of the Metzler \& Tjeerdsma (1998) DRI Model. More specifically, the research questions addressed in this paper are linked to the recruitment phase of teacher socialization.

Templin et al. (1982) referred to recruitment as anticipatory socialization. They suggested that socio-cultural as well as psychological factors might contribute to, influence or facilitate an individual's decision to enter a given field. Dewar \& Lawson (1984) describe recruitment as, '... the process whereby an individual becomes attracted 
to and makes the choice of a particular occupation' (p. 15). Lawson (1983b) argued, 'the socialization of physical education teachers begins in early childhood, results in a subjective warrant for teaching physical education and continues upon entry into teacher education programs' (p. 3). This phase of socialization into teaching is characterized by questions such as: Why does one enter physical education? What effect do childhood experiences and one's education have on an individual's decision to enter physical education? These are the types of questions that have been of increasing interest to researchers in physical education since the early 1970s (Belka et al., 1991; Templin \& Schempp, 1989). One of the most important questions about the recruitment phase of socialization is 'Why do people choose to enter the field?'

Dewar and Lawson (1984) stated that understanding the subjective warrants that people have for the profession of physical education is crucial for a complete understanding of recruitment into the profession. Lawson (1983a) suggested that if we had a better understanding of who our recruits were and what their beliefs were about teaching, schooling, and physical education, that we may be able to better design, sequence, and present professional content to ensure a more robust teacher education programme. Further, an increased understanding of prospective teachers' perceptions and beliefs about teaching physical education may enable teacher educators to better socialize them for their role as physical education teachers.

Following Lortie's (1975) concept of occupational choice, Templin et al. (1982) examined the process of occupational choice within a physical education context. Lortie's (1975) paradigm of occupational choice is grounded in the notion that an occupation must possess various recruitment resources to attract an individual to the profession (Templin et al., 1982). Lortie (1975) identified two types of recruitment resources: (a) attractors; and (b) facilitators. Attractors are defined as, '... the comparative benefits proffered would-be entrants ...' (Templin et al., p. 121). Attractors to the profession include material benefits such as money, employment security and social mobility, and/or psychic/symbolic benefits such as: prestige, power and satisfaction. Facilitators are, '... the social mechanisms which help move people into a given occupation' (Templin et al., 1982, p. 121). Facilitators may be exemplified by the influence of significant others, the absence of occupational alternatives, and/or the subjective warrants of recruits (Dewar \& Lawson, 1984; Templin et al., 1982).

Lawson (1983a) and Dewar and Lawson (1984) identified three themes associated with recruitment into teaching physical education: (1) continuation theme; (2) ease of entrance into physical education programmes; (3) interpersonal/service theme. Students with extensive primary (within the family) and secondary (within school, university, and other organizations) involvement in sport, physical activity, and physical education tend to be attracted to physical education. Dewar and Lawson (1984) added that recruits into physical education view physical education as a way to continue an association with sport and physical activity, which they perceive as enjoyable and rewarding. Students did not view entrance requirements or academic rigour of physical education programmes as barriers to their aspirations to join this field (Dewar \& Lawson, 1984). Lortie (1975) and Dewar and Lawson (1984) suggested that recruits into physical education tend to have the desire to work with and help others as well as believe the profession provides a valuable service to society.

While much of the literature on teacher socialization has been focused on 'traditional' undergraduate students (ages 18-22), Hutchinson and Buschner (1996) pointed to the changing demographics of students currently entering higher education. Kasworm (1990), as cited in Hutchinson and Buschner (1996), suggested that nearly $40 \%$ of all 
current undergraduate students are 25 years of age and older. Teacher certification (professional preparation of recruits) occurs at the graduate level at University X. As graduate students, these adult learners are entering their academic teacher preparation programmes with rich life experiences, diverse reasons for entry and distinctive motivational purposes (Hutchinson \& Buschner, 1996; Knowles, 1984, Manos \& Kasambira, 1998). How are adult learners different from the 'traditional' students who entered higher education in the past 20 years? Hutchinson and Buschner (1996) state that while many fields are beginning to explore how adult learners differ from traditional students, adult learners have not been the focus of research in PETE (p. 205). Considering the changing student demographics and a shift of teacher certification to the graduate level, it is timely to explore the process of socialization for older students. Hutchinson and Buschner (1996) addressed the lack of research on socialization for delayed-entry undergraduates. The present study has the potential to address anticipatory socialization issues for graduate students and the research phase of Metzler and Tjeersdma's (1998) DRI model.

\section{Purpose and Research Questions}

The purposes of this study were to: (1) identify what attracted the graduate students at University $\mathrm{X}$ to the field of physical education; (2) identify what situational and/or social factors facilitated this career decision; and (3) describe their beliefs about what it means to be a physical education teacher. There were two main research questions that provided parameters for the study. First, why did these students want to be physical education teachers? Second, what are their beliefs about physical education teaching or teachers?

\section{Methods}

This study was part of a larger research project on the efficacy of a teacher education graduate programme to prepare prospective physical education teachers to provide a socially responsible physical education curriculum that meets the needs of students in schools during the twenty-first century.

Subjects

A total of eight students entered the M.Ed. programme in the summer of 1996. Pseudonyms are used for all eight students throughout this paper. Seven students completed the programme and one withdrew on advice of the faculty. This student was granted permission to re-enter the programme the following year contingent upon resolving a number of academic and personal issues inhibiting his ability to be successful. Three females and four males were full-time students in the programme. This included a Native American male (Terry), two African-American males (Niall and Tony), three Caucasian females (Fiona, Jean and Gail) and one Caucasian male (Dara). The Native American grew up on a reservation in a south-western State, both African-American males grew up in urban centres, one Caucasian male grew up in the suburbs, and the remaining three Caucasian females came from small, rural mid-western towns. Five of the students were from the mid-western region of the US, one from the south-east and one from the south-west. Two of the four male students were married and had one and three children, respectively. One of the three female students was married and none had children. 
The educational background of the students varied. Only one had obtained their undergraduate degree in health and physical education (Niall). Three had obtained their degrees in allied fields; Dara in recreation education, Tony in outdoor education, and Jean in therapeutic recreation, while Terry, Fiona and Gail received their undergraduate degrees in biology, deaf education, and textile management, respectively.

\section{Setting}

This was the first cohort of students admitted to a new M.Ed. programme designed to prepare physical education teachers to teach. The programme began with a week-long (20 contact hours) orientation to teaching in late August and was followed immediately with a 3 week internship in elementary and secondary school sites where pairs of students observed and assisted mentor teachers preparing for and starting the school year. A weekly meeting on campus allowed students to debrief each other and faculty on their experiences and how they were applying what they had read and discussed about schools, diverse learners, and creating supporting educational environments for physical education. One such assignment had M.Ed. students observing what, how and why teachers set students' expectations for their physical education programmes and the nature and scope of the rules and routines for student behaviour while in physical education classes. These pre-service students returned to campus for fall quarter classes. During fall quarter, students took the following courses: equity in teaching, technology in education and physical education, effective teaching in physical education, and curriculum and instruction. They also completed an internship aligned with the curriculum and instruction course observing and interacting with teachers whose curricula reflected exemplars of different approaches to elementary (sport education, movement education) and secondary physical education (fitness education, sport education and tactical approach to games teaching). During winter quarter, students completed a combined elementary pedagogy course and an elementary internship co-taught by a faculty member and a clinical educator.' The same format occurred in spring quarter for secondary physical education. Students also enrolled in two professional seminars. One seminar met throughout the year addressing the macro-politics and micro-politics of teaching, schooling and job searching. Topics included physical and sexual abuse of children, State initiatives to restructure physical education and the school curriculum, authentic assessment strategies, technology and web site resources for physical education, and job searching. The second seminar provided guidance on the design and presentation of their M.Ed. project focused on some aspect of teaching and learning in physical education for which students received additional research credit. A number of these projects were action research projects on issues of interest to the students and were completed during their internships.

\section{Data Collection and Analysis}

Several data sources were used to address the two research questions in this paper. They included interviews, analyses of M.Ed. students' autobiographical statements, and observations of their teaching, critical incidents from their teaching and peer responses to critical incidents. An outside professional educator visiting University $\mathrm{X}$ and a faculty member who was not directly involved with teaching any professional preparation courses conducted the initial interviews of the M.Ed. students. The interviews occurred upon completion of the first internship and 2 weeks into the start of the fall academic 
quarter of full-time study. These interviews were face-to-face and open-ended following a general interview guide approach (Patton, 1990). Each interview took place on campus, lasted approximately 60-90 minutes, and was audiotape recorded. Faculty and doctoral students transcribed each interview verbatim. The transcripts were read and analysed for emergent themes related to the research questions. Students wrote two scenarios, one about their elementary internship experience in winter and one on their secondary experience in spring. All students responded three times in spring and winter to one of two scenarios posted by the M.Ed. students and stemming from their 8 week internships. Data that addressed either of the research questions were culled from the students' writings. The students' autobiographical accounts of entering teaching were a third data source. Multiple data sources, various data collection methods, and consistent peer debriefing amongst the faculty and doctoral students were used as strategies to enhance the credibility of the findings.

\section{Findings}

\section{Why did the M.Ed. Students want to be Teachers?}

The M.Ed. students' perspectives of why they wanted to teach were gathered from two main sources; interviews held with each prospective teacher 1 month into their M.Ed. programme and the autobiographical statement completed by each student in the spring quarter of their programme. The students wrote the autobiographical statement after completing their elementary internship and prior to their secondary internship. The statement became part of a teaching portfolio that the students created during the year explaining why they wanted to teach and the influences that shaped their decisions. Additionally, relevant comments on their career choice in three scenarios and responses to scenarios posted to M.Ed. peers and instructions on issues of concern or interest during their secondary internships were also reviewed for insights into this question. All students posted at least two scenarios and replied to one of the two scenarios posted by peers in each of 4 weeks during both internships.

In an effort to identify themes that attracted and/or facilitated their choice to teach (Lortie, 1975), the students were asked to talk about what influenced their decision to become a physical education teacher.

A strong commitment to teaching. All of the students in this cohort group of prospective physical education teachers knew they wanted to teach. Niall always wanted to be a physical education teacher. 'I knew it was what I wanted to do with the rest of my life. In fact when I went to college, I enrolled in public administration. I think I was interested in being in it because I thought I would make more money. But it was not comfortable there'. Niall switched his undergraduate degree to physical education and the M.Ed. was a chance to further his education and gain teacher certification at a larger institution.

Fiona was already a deaf educator when she applied to the M.Ed. programme. She did not want to be a physical education teacher, but needed to get the physical education teacher certificate to get the adapted validation certificate she was seeking. About her deaf education degree she said, 'I knew I didn't want to teach reading, math, social studies ... the academic side of it ... but I did want to teach.' Responding to 'what is so appealing about the gym,' she said, 'just the physical nature of it ... just the getting up and getting to be physical, getting to teach, games or sports ... because those are what I enjoy the most. That is where my interest is. I think I was successful [teaching in the 
classroom] but it did not come naturally, whereas teaching physical activities does come naturally.' Fiona had the option to obtain dual degrees (M.A. and M.Ed.). Because her graduate programme was supported through a grant, she decided to use the extra time to pursue both degrees though her intent was to teach adapted physical education upon completion. Fiona chose a career teaching elementary physical education in one of the few urban schools to have two full-time physical education specialists.

Dara decided to pursue teaching once he realized he was not going to have a professional baseball career and he could not see himself working a 'desk job' for a long time. His review of his life's interests, his coaching experiences, and conversations with his physical education teacher helped him choose teaching as a career.

Describing what influenced his decision to become a physical education teacher, Tony said, 'well I would say it's definitely a career change but I would say also that it's definitely part of a plan.' Tony had always wanted to 'do' education but changed his mind and completed an outdoor education (non-teaching) degree. He applied to education initially but 'I had this thing about the outdoors' and when 'I saw [on] the form, outdoor recreation, it just clicked. So I just changed it and went that way'. After completing his undergraduate degree he worked for 2 years as a naturalist and another 5 years with a Parks and Recreation Department in a small town. He said he noticed beginning teachers 'could enter a school and make more money than I was making with 4 years professional [experience]. This was somewhat persuasive in helping me make a decision to change fields. Not that money is an issue ... the dynamics of everything ... that's really where I got the motivation and desire to come back to school.' He described his previous job as very stressful and time consuming and added, 'I was basically responsible for everything from cleaning to teaching to lesson plans and things like that.' Tony obtained a dual M.Ed./M.A. degree and is now teaching as an elementary special education teacher in his local school district. He has some physical education classes and a long-term goal is to move into a physical education position. He is also pursuing more graduate work in Special Education and looks to completing a doctoral degree in teacher education in the future.

Gail wanted to be a physical education teacher and complete a physical education degree as an undergraduate. But she did not think it was glamorous enough at the time as her goal was to end up in New York City. 'So I went into textiles and clothing and moved to New York City working in clothing and textiles'. She returned to the mid-west and worked in commercial art for 6 years. Before this business closed down Gail began studying for and later passed the personal training test from the American College of Sports Medicine (ACSM) and became a personal trainer. She still wanted to further her education and 'I really wanted to do education, so I believe I started this a year and a half ago or two ... I had to take 10 classes to get into the programme. Then it just evolved. I knew I wanted to do it since I worked so hard just to try to do it'. Gail is now a secondary physical education teacher.

Jean entered the M.Ed. as a means to an end. She had a degree in Recreation with an emphasis on students with disabilities and wanted to become a programme developer for students with disabilities. 'I knew it would be a lot harder for me to get to where I want to go (program developer in camps) with only that background. I don't feel I gained a lot from my undergraduate degree. I need to further my education, my knowledge. Of the choices that I had, I think physical education was (closest to what I knew and needed), and now I am glad that I made that decision'. Her major goal in life 'is to someday ... have my own adventure-based camp, preferably out West for people with disabilities'. Jean completed her second master's degree (M.A. in Adapted Physical 
Education) and began teaching in Oregon as an adapted physical education consultant in a progressive school district that she sees as 'just the perfect opportunity for me'.

Terry had the most extensive life experiences before deciding to be a physical education teacher. He said, 'back in high school I wanted to be a [physical education] teacher. I looked up to my [physical education] teachers in high school even though they were pretty bad - I still wanted to be one because it is our [Navaho] traditional way to incorporate physical fitness and spirituality. I always wanted to be a PE teacher to teach that physical fitness is important.' Terry believed he received a poor public school education and 'graduated from high school with a very low Grade Point Average (GPA). I knew I would not be accepted in college. I was ill prepared. I could barely read, write or do math'. Terry competed in rodeo for about 4 years. He added, 'After I was hurt, I became a construction worker, working there until I was 28 years old.' Then he decided it was time to fulfil a lifelong ambition. He went back to school, got a degree in biology and decided to continue with a master's degree but focus on physical education teacher certification while his wife completed her teaching degree in art. Terry finished his degree and accepted a teaching position in an elementary urban parochial setting and then returned to his home State to pursue a teaching career there.

Enjoyed children and working with them. Niall wanted to teach because he loves kids and likes to teach. As he said, 'I just love the culture, especially the health and physical part of it. I love it. That's the only thing I think I would like to do for the rest of my life. I found myself really getting into it and in knowing that I'm pretty good at it and with working with children at the same time.' Fiona's greatest influence to pursue teaching physical education came from her love of working with kids. While working at the YMCA she realized 'that not only did I miss being in the gym and getting to teach different activities and not just one sport, but I missed the kids with special needs'.

Significant others as facilitators The students in the M.Ed. cohort described teachers, coaches, family members, friends and the children with whom they worked as motivators for them to pursue teaching careers in physical education. Niall noted that two people influenced his decision to teach. One was his high school physical education teacher and coach and the other was a professor at his undergraduate institution. His high school teacher:

... influenced me throughout my college career and throughout my last year of high school ... [Because of the experiences helping the PE teacher and because of his influence] ... I really just wanted to be a physical education teacher. [I thought] I would enjoy that. His university mentor used to talk about his (current) university so much. I really did well in his class because he made class interesting. That's why I came here ... Because he really did make you want to learn because he knew so much. I knew if I wanted to be a professor like him and some other professors in my department, I knew this [going back to school] is my first step - my master's program.

Niall received a couple of offers to teach physical education in urban settings and began his teaching career in an urban high school in an eastern State. Fiona's high school physical education teacher/coach was a positive role model for her but that had been 10 years earlier, and she was not sure if that really influenced her. She had shied away from teaching physical education and struggled for 10 years with her decision to teach physical education because of what she acknowledged was 'the stigma of being a female in the 
PE world ... my perception coming out of high school was that female PE teachers were all gay ... just negative [perceptions] ... which is ironic because I just adored my PE teachers'. Dara's secondary school physical education teacher/coach was a key factor in his decision. His mother, who is also a teacher, was a role model for him in his career choice.

Five different individuals influenced Tony to become a teacher. All were either his teachers and/or coaches: a teacher at elementary, high school and college and/or two coaches at high school and college. They provided him with opportunities to observe and discuss what teaching was about and allowed him the chance to assist as a coach. When Tony completed his recreation degree, he developed a closer relationship with his elementary teacher/high school coach and went to observe him teach several times. Observing his mentor in the school system Tony began to realize that 'I hate to say this, but I said I could do this (if not as good, better)'. Listening to his mentor speak about the difficulties of being an elementary teacher and a high school coach further influenced Tony to pursue a teaching and coaching certification at the secondary level.

Gail was influenced by two people in her choice to become a teacher. One was a teacher and the other was a coach. First was her grade school physical education teacher whom 'I loved ... he was my favorite teacher probably ever' and her sister's softball coach who spotted her talent for running and encouraged her to compete.

Jean spoke to a number of people before deciding to join the M.Ed. programme. Her boss at camp was the greatest influence on her going back to school. Jean said, 'The director from the center, my boss at the camp, has her Ph.D. in physical education [from this university]. She is where I'd like to be. She is a program developer at RU [recreation camp for children and youth with disabilities]. She is a very good role model for me.' Peers who had already completed the teacher certification programme at the university were another source of information that convinced her to complete the degree there. Working primarily with children and adolescents with disabilities was the greatest source of motivation for Jean to begin the degree programme.

Terry articulated some of the strongest familial influences in his decision to become a physical education teacher. Terry's wife and grandfather were critical in his decision to go back to school. 'My grandfather woke us up in the morning to run to the edge of the horizon to pray before the sun came up. He and my uncles stressed that one has to be physically fit'. After his rodeo accident, Terry said 'I got married to a Navaho girl from my home town, a smart Navaho girl who went to several universities. She was raised in California in a foster home. She had a pretty good foundation of school. I give her a lot of credit - she made me go back to school.'

Past sporting experiences facilitated entry into teaching. The students who participated in this research project described a variety of past sporting experiences that were also influential in their decision to become physical education teachers. Their sporting experiences ranged from participation in competitive sport through assisting or being responsible for delivery of instruction in school, camp and/or related recreational situations. Niall assisted in high school physical education classes taking roll and planning out activities and was a successful and popular athlete from elementary through high school and a member of the college dance team. Fiona loved physical education in school and was excited with whatever they played in the gymnasium. Participation in sport was important because with serious problems at home, sports at school and in class were her refuge. 'Anytime I could get a pass to go to the gym, I took it. My coach who was also 
my PE teacher was the most influential person in my life for those first three years of high school'.

Sport was Dara's life until college. He was a varsity baseball player with aspirations to compete in the major leagues. When that faded he coached baseball and enjoyed it. In public school his only interests were in sport and he loved physical education. His academic work was not great despite constant tutoring from his parents, but his sense of identity evolved from his success on the sport's field.

Tony liked sports and was an athlete in several sports in high school and played soccer at college. His father had been an Olympic caliber boxer. He also coached soccer. In his youth, sport was part of his life and at times, as it was for Fiona, sport was a refuge from troubles at home. It was his chance to 'get out and perform ... do my thing and be successful'.

Gail described herself as an active sports-person all her life. She was a runner in school and has always worked out lifting, cycling, and swimming. She taught swimming lessons for 5 years in the city and was a lifeguard at the city pools. 'I enjoyed it, teaching, especially the younger people; I mean the adults which I teach now [personal training] are fine, but they're a lot harder to get through to than the younger ones. It's easier to teach, to me, swimming to a young person than it is to someone who already has ideas in their head and they won't change them at all'. Prior to the M.Ed., Gail made a living as a personal trainer. 'I usually start work at 5:30 or 6 in the morning before they start work. Usually work for 2-3 hours with clients every morning'.

Jean's experiences with sport were unlike anyone else in this M.Ed. cohort. She felt she was 'just average in sports'. She had played volleyball in high school and softball in her community but hated physical education, as she had been 'an overweight child'. During a methods class and a demonstration of fitness lessons Jean shared in a debrief session how some of the activities we had just completed brought back a number of hurtful times for her in the physical education class. A significant concern surfaced when Jean made an emotional plea to her peers and to faculty to be sensitive to young children who perceive they can not succeed at some of the tasks we set in physical education lessons. Jean always liked outdoor activities such as hiking, cycling, horseback riding '[though] those really had nothing to do with school'.

Although Terry did not recount participating in any organized, competitive sport as he grew up, his experiences with his (Native American) family ritual of running each morning toward the sun was an important foundational background to his desire to become a physical education teacher.

The impact of past academic experiences on entry into teaching. There were positive, negative, and indifferent undergraduate experiences that played a role in the students' decisions to pursue teacher certification. Each student has a unique story of how their undergraduate careers evolved into their decision to pursue teacher certification at the graduate level.

For Niall, his experiences at college and his work in physical education classes were very important to him. He liked his professors and his classes and took them seriously. He is proud of how hard he worked and his success in classes encouraged him to 'go the extra mile with assignments and made me more attentive in classes. I really wanted to know what we were doing'. His professors pushed the importance of physical education and how 'to uplift our discipline to a higher level'. Niall then wanted to take his education to 'another level' (advanced degree training and teacher certification).

Fiona's undergraduate degree in special education was to work with hearing-impaired children in the classroom and her interest in adapted physical education is a further 
extension of this career aspiration. As such, Fiona could increase her marketability and extend the work she did with special populations by gaining certification in physical education.

Once on his way to a potential career as a professional athlete, Dara's decision to quit the varsity baseball team forced him to re-evaluate what to do with his life. His grades were poor but he still had to declare a major. During his major he was introduced to 'coaching baseball through field experiences'. As he participated in this internship he realized, 'I enjoyed teaching children what I had learned about the game'.

Tony still had education in mind while completing his recreation degree and opted for an internship in a recreation and parks programme to work with children and youth rather than complete a minor in sociology. He stated, 'Education was still on my mind because I was checking to see how I could pursue this education degree even as a recreation person.'

Gail wanted to further her education. Completing a personal training certification gave her confidence to return to graduate school. She said that the coursework in exercise physiology and kinesiology from the personal training programme made taking the prerequisites for entry into the M.Ed. programme 'pretty easy'. Further she felt that a master's programme that could be completed in 1 year was also very appealing. 'I could actually get a Master's doing this and I really wanted to ... the thought of having to go through another [undergraduate] degree [was not appealing]'.

One of Jean's undergraduate internships was at a camp. She was a programme staff person. Describing this position she said, 'we taught sixth grade environmental education. I really enjoyed teaching. It was a neat atmosphere.' She also worked at three other such camps and thought this would be a nice way to focus her career.

At 28 after competing in the rodeo and working in construction, Terry applied to school. It was a long and difficult process. After his second appeal:

They accepted me. I started with very basic classes, learning math and spelling. Then I went through the biology program. I am glad because I could incorporate the Navaho philosophy with a biology major, but I did not want to be a biologist or a researcher. I thought I could teach, but I would have wanted to do it my way, the Navaho way, and I knew they wouldn't let me ... I took PE classes. I still wanted to be a PE teacher.

Other instructional/educational experiences facilitate entry into teaching. Each student described personal experiences they had as students in their initial careers. This provided them a feeling of what it would be like to teach and gave them the idea that teaching (physical education) is what they wanted to do.

Niall's high school had a programme called 'teacher's reverse role day' when the student plays the teacher. 'So I had a chance to do that for two classes for two different teachers, two different days, and I really enjoyed it'. Fiona felt that she had some of the skills necessary to be a physical education teacher because of the coaching experiences she had over the past 6 years. She said, '... having to really assess [the skill] for the very first step to the next step ... I've been working with kids in some capacity for the past 8-10 years. I really love that ... it was difficult for me to leave the kids I had been working with for years to move here [and go to school].' Gail stated that successfully completing the ACSM personal training certification was a big confidence booster to completing a teaching degree. Jean's work in a variety of camp experiences was a major factor in her decision to seek a teaching certification and adapted physical education validation. 
Terry had, what he termed, two life-triggering events that brought him to teaching. The first was a very serious rodeo accident:

I got hurt real bad while rodeoing. I was in a cast for about 8 months. I saw what was going on, how basically dysfunctional every body was. The question was - what would I like to do for the rest of my life? I went back to rodeo ... I was nervous though I rodeoed well. But I was not hungry for it. Something was missing. I started thinking about college again after the accident. I was not ready to go back knowing that I would have to take really basic courses ... I became a construction worker. I was living out of suitcases, falling into the same cycle ... alcohol.

The second major event was moving with his wife to the mid-west. Terry noted:

My wife was recruited [by local Research University] and wanted to come here to do her graduate work. I was reluctant at first. We loaded our pick-up truck, found a place to rent. My wife started her program. I immediately enrolled in a continuing education program and came directly here (the school of HPER); they referred me to [faculty member]. Here I am the happiest guy. It took me 35 years to find where my heart really is.

Family and friends were not (initially) helpful in facilitating entry into teaching. Family members (with the exception of Terry) tended not to be the most influential people in these students' decisions to become physical education teachers. While family support may have waned initially, most students describe a change of heart and increased support from family (and friends) once they understood how important this was to their future. As a result, their family and friends became more educated about physical education.

Niall's family thought physical therapy was what he was majoring in, not physical education (lasted for about 1.5 years). Family is now 'ready to help me, though I'm not doing it for them. I really enjoy learning now'. He is also the first of his peer group to continue school. 'A lot [peers] look up to me and that's fine because we can see if we can get up there at the same time [advanced education]'.

Fiona's family was not supportive initially, asking her why she was going to teach physical education. After she explained her reasons she said they were 'real supportive' though her mother was surprised at first by her choice to go into the gymnasium and not the classroom. Most of Fiona's friends are in some aspect of physical education as a career so they also have been very supportive.

Tony's wife was particularly supportive of his decision to pursue teaching credentials but worried about maintaining the [financial] stability of their family during the 2-year programme. Tony's mother and sisters were also supportive but most of his peers expressed negative opinions. 'Their reaction was ... well you don't want to get into that. That's a dead field. And what are you going to do with physical education ... you're not going to be able to get a job'.

Gail's family and friends were supportive of her career move. 'They asked a few questions, [like why do you have to get your master's to be a physical education teacher?], but since I was already a personal trainer, it didn't shock them I was changing careers'. Earlier they [her friends] had been supportive when she pursued her personal training license, moving away from the art field. However, when she asked her favourite elementary physical education teacher to write a recommendation for her application to the M.Ed., he responded, telling her 'he would give her a wonderful reference', but also told her 'I don't know why you want to do that'. 
Jean's mother had a hard time with her decision initially. Her mother said, 'You want to be a Mrs. S., a gym teacher!' 'Jean had to explain the difference. But they have been very supportive [once they knew I was serious]'.

The most important factor(s) that facilitated and/or attracted students to teaching. The students found it difficult to identify any one person and/or experience that was most influential in their decision. Yet, there were two common threads: the enjoyment or love of physical activity and their desire to work with children. Niall's interest in children, his love of physical activity, help of a college professor to pursue his teaching goal, and a graduate assistantship have been key factors in his pursuit of his teaching degree. Fiona's desire to work with children with special needs and to teach them the content (sports and physical activities) she loves have been the key factors in her choice to obtain a physical education teaching degree and adapted physical education validation. Dara's positive experiences coaching during his undergraduate programme was the key factor in choosing teaching as a career. For Tony, the difference in long-term career opportunities as a teacher and recreation leader and his continued involvement in coaching with a physical educator were key factors. Gail's desire to be an educator was a key factor in her career shift. She was strongly influenced by her success and enjoyment of teaching and liking of kids, which she had been doing for 5 years since her return from New York City. Jean's experiences with special needs students in a variety of camp settings were influential in her decision to enter the teaching programme. It should be noted here that originally Jean had no intention of teaching in a school (urban, rural or suburban). However, her internships in elementary and especially in an urban high school had a profound effect on her. She was much more open to the possibility of teaching once her adapted physical education master's was completed the year after her M.Ed. programme. Indeed her first position upon graduation was as an adapted physical education teacher and consultant for a school district. Terry's family was the biggest influence on his considering teaching physical education as a career. 'They were also good role models'. His wife, however, was the immediate catalyst, encouraging him first to go back to school to get a degree and then supporting his move to complete his master's degree to teach.

\section{Beliefs About Teaching}

The second research question addressed the M.Ed. students' beliefs about physical education teaching or teachers. Five themes emerged from the students' responses. They believed that being a physical education teacher meant the following.

(1) Helping students know about and appreciate the importance of physical activity. When describing what she believed to be the role of the physical education teacher, Fiona said, 'it's up to the physical educators to figure out how to accomplish the task of showing their students that physical education is important for every age and every level.' Terry believed that physical education teachers are in a good position to help students understand the importance of physical fitness and that it is their responsibility to 'figure out what is going to motivate kids to want to be physically active'. Niall believed that his physical education teachers helped him a great deal. He said, 'I had a lot of help ... so as a PE teacher I can help ... I can help a lot.' Gail also believed that physical education teachers can 'help students understand the importance of physical activity and fitness'. 
(2) Physical education teachers could contribute to the development of students' self-esteem, especially those students who are often marginalized in physical education. Fiona believed that physical education teachers can 'help students understand that physical activity is important for everybody - every age and every level [of ability]'. Like Terry, Jean had negative experiences with physical education. She 'wants to avoid being like [my] PE teachers' and believes that teaching physical education would be a way to 'build children's self-esteem ... help those who are having a hard time ... provide equal opportunities for all children'.

(3) Physical education teachers could be role models for a healthy and active lifestyle. Fiona believed that physical education teachers 'are role models - not just talking but showing it and doing it everyday'. As Terry reflected on what he called his experience with 'bad physical education teachers in high school', he stated that being a physical education teacher meant, 'being physically active with them [children]'. Niall believed that physical education teachers have to be 'a role model ... be a model PE teacher - practice what you preach'. Adamant in her belief that physical education teachers should be role models, Gail said, 'PE teachers should not be unfit.' Jean believed that physical education teachers are 'role models in sport, fitness and adventure'.

(4) Physical education teachers should have a good understanding of their content beyond doing activity. Terry believed that physical education teachers should find ways to make physical education relevant to children's lives and that physical education should be extended to family, work and community. As Niall described his belief about being a physical education teacher, he said, '[physical education teacher] must be diverse in your approach to teach ... PE teachers have to have knowledge of content.' Jean believed that her physical education teacher certification would afford her opportunities to do 'other' types of work - such as work in community recreation.

(5) Physical education teachers should have content knowledge and pedagogical knowledge (where pedagogy is about motivating students, exemplifying the meaning of physical education in their lives as physical education teachers). As Niall talked about what he believed to be the positive aspects of physical education, he said that the physical education teacher's role is 'to teach and help somebody learn what physical education means to me.' He added, '... it's [teaching physical education] more than being a PE teacher ... it's about being a teacher, period.'

\section{Discussion}

This study is part of a larger study on the socialization of graduate students in a M.Ed. programme in an effort to explore how changes to teacher certification at the graduate level are improving teacher education (Metzler \& Tjeerdsma, 1998). The primary focus of this portion of the study was the anticipatory socialization (recruitment) of the first cohort of graduate students admitted to the M.Ed. programme. There were three purposes for the present study. First, we wanted to identify what attracted older (graduate) students to the field of physical education. Second, we sought to identify what situational and/or social factors may have been influential in this career decision. Finally, we hoped to describe what it means to these students to be physical education teachers. There were two research questions that provided the foundation upon which we could explore the anticipatory socialization and subjective warrants of this cohort of graduate 
students. The research questions were: Why did these students want to be physical education teachers? What are their beliefs about physical education teaching or teachers?

The majority of research on teacher socialization in physical education is focused on traditional-aged students (Hutchinson \& Buschner, 1996). Prospective physical education teachers in this present study were also different from traditional cohorts of prospective physical education teachers because they were older than traditional-aged students and many of them had previous career and educational experiences in areas other than physical education. Like traditional cohorts of students, these M.Ed. students described anticipatory socialization experiences that were similar to those described in previous research on the recruitment phase of socialization (Dewar \& Lawson, 1984; Hutchinson \& Buschner, 1996; Lawson, 1983a, 1983b; Lortie, 1975; O’Bryant, 1996; Stroot \& Williamson, 1993; Templin et al., 1982). They were attracted to the field by the love of the content, the dynamics and culture of the work in sport and physical education settings, and the opportunities to work with young people. Similarly, their anticipatory socialization was facilitated by social and situational factors, such as the support of family and friends, positive experiences with teacher-mentors, and subjective warrants for physical education (Dewar \& Lawson, 1984; Lawson, 1983a; Templin et al., 1982).

Perhaps the most striking difference between this cohort of students and traditional cohort rests in what influenced their decision to teach - namely their strong commitment to teaching. As a group, these recruits were more focused on teaching, not coaching. An additional difference observed with this particular cohort of students was the diversity (racial/ethic and experiential) among them and their openness to a multi-cultural PETE programme. There is a lack of ethnically diverse physical education teachers in US schools (O'Bryant, 1996). Exploring the anticipatory socialization of African-American women into physical education, O'Bryant (1996) noted that a focus on multi-cultural issues in teacher education programme is an important issue for African-American women who have chosen to teach physical education. There was no doubt that not only was this particular group of prospective teachers quite a diverse group, they also articulated views that supported and affirmed the values of a multi-cultural approach to teaching and learning. As Hutchinson and Buschner (1996) observed with delayed-entry undergraduates in their study, we found that the M.Ed. students in the present study described life experiences that prompted them to reflect upon their career goals, re-evaluate them, and pursue a career teaching physical education. The prestige of becoming a physical education can be problematic for recruits into the field (O'Bryant, 1996). Most of these students did have friends or family who were not initially impressed with their decision to teach - in fact openly questioned it. While the family and friends of this cohort of students changed their minds as they became more knowledgeable about the depth of professionalism in physical education and the students' excitement about their chosen profession, their initial reactions are evidence that the general public does not tend to view the choice of a career in this field very highly.

One of the positive aspects of alternative teacher certification programme across the US - despite widespread criticism of them as lacking time for adequate teacher preparation - has been the success in attracting a greater percentage of prospective teachers from underrepresented groups to teaching. This cohort had a greater diversity than we were ever able to attract in the traditional programme. This aspect of the programme has continued since the inception of the M.Ed. programme 4 years ago.

This cohort of students was primarily interested in and committed to teaching (as opposed to coaching) and equity in the curriculum and in their work with children. These two trends observed in this cohort of students appear to fit core values and shifting 
paradigms linked to diversity and improved quality of teaching in teacher education programmes. Perhaps faculty in PETE programmes should consider that older, non-traditional students (undergraduate or graduate) bring life experiences (personal and professional) that will enhance their professional socialization.

\section{Future Research}

Participants in this study are more focused on teaching and more aware of and interested in the diversity of learners with whom they will work in schools. These differences combined with programmatic changes at our institution - namely the focus on schoolbased and inquiry-based teacher education and teacher certification at the graduate, raise a variety of questions for future research. The move to school-based teacher education in professional development schools (Holmes Group, 1986) reflects both a technical and inquiry focus to teacher education. Examples of such a focus can be found in the assessments that students completed throughout the programme. Examples included action research projects, clinical supervision internships, teaching portfolios (to demonstrate their planning, instructional and assessment competencies), a professional autobiography at the beginning of the programme followed by a critical reflective essay as a teacher at the end of the programme with several opportunities to reflect on and discuss teaching throughout.

Like other Holmes institutions, there has been the creation of a new 'faculty' position known as the clinical educator. Current teachers act as clinical educators and are invited to contribute to the professional development of pre-service teachers either co-teaching their methods classes, supervising their teaching in schools, or by facilitating a professional seminar that discussed both macro and micro aspects of the teaching profession. There is a paucity of research on the effectiveness of clinical educators in teacher education programmes. Are their roles in the professional development of graduate student teachers wise practice or are we adding yet another task to the already overburdened lives of physical education teachers? What are pre-service teachers learning in increasingly school-based teacher preparation programmes? How well are they prepared to teach in urban schools and under-served populations?

This study raises more questions than it does answers about the aforementioned issues. As with O'Bryant's (1996) findings, this cohort of physical education teachers had a sensitivity to a range of multi-cultural issues (gender, ability, ethnicity), and their views and beliefs about teaching and learning challenged some of the more traditional approaches to class management and instruction. Given our need and desire to recruit more prospective teachers like this cohort, it seems critical that we come to better understand what pre-service teachers believe. Perhaps the contribution of this study will be to highlight the need for teacher educators to be even more cognizant of pre-service teacher beliefs as they design and deliver professional preparation programmes to prepare socially responsible teacher educators who can enhance the success of all students in their care.

Correspondence: Camille P. O'Bryant, Department of Physical Education and Kinesiology, Cal Poly State University, San Luis Obispo, CA 93407, USA. Tel: (805) 756-2545; Fax: (805) 756-7273; e-mail: < cobryant@calpoly.edu > . 


\section{Note}

[1] Clinical educators are local master teachers who are secunded part time from local schools to team-teach the methods coursework with faculty, to supervise and mentor beginning teachers, and provide leadership and mentorship to local teachers. All this is part of our Professional Development School initiative that has a three-fold purpose: to better prepare teachers for urban schools, to improve local physical education programmes, and to improve the professional development of practicing teachers.

\section{References}

BELKA, D., LAWSON, H. \& LIPNICKEY, S. (1991) An exploratory study of undergraduate recruitment into several major programs at one university, Fournal of Teaching in Physical Education, 10, pp. 286-306.

DEWAR, A.M. \& LAWSON, H.A. (1984) The subjective warrant and recruitment into physical education, Quest, 30, pp. 15-25.

FERNANADEZ-BALBOA, J. (1997) Critical Postmodernism in Human Movement, Physical Education and Sport, (Albany, NY, SUNY Press).

FULLAN, M., GALLUZZO, G., MORRIS, P. \& WATSON, N. (1998) The Rise and Stall of Teacher Education Reform, (Washington, DC, AACTE).

FULLER, F.F. (1969) Concerns of teachers, American Educational Research Fournal, 6, pp. 207-226.

HOLMES GROUP (1986) Tomorrow's Teachers: A Report of the Holmes Group, (East Lansing, MI).

HUTCHINSON, G.E. \& BUSCHNER, G.A. (1996) Delayed-entry undergraduates in physical education teacher education: examining life experiences and career choice, Fournal of Teaching in Physical Education, 15, pp. 205-233.

KIRK, D. (1986) A critical pedagogy for teacher education: toward an inquiry-oriented approach, Journal of Teaching in Physical Education, 5, pp. 230-243.

KNOWLES, M.S. (1984) Introduction: the art and science of helping adults learn, in: Andragogy in Action: Applying Principles of Adult Learning, pp. 1-21 (San Francisco, CA, Jossey-Bass).

LAWSON, H. (1983a) Toward a model of teacher socialization in physical education: the subjective warrant, recruitment and teacher education, Journal of Teaching in Physical Education, 2(3), pp. $3-16$.

LAWSON, H. (1983b) Toward a model of teacher socialization in physical education: entry into schools, teacher's role orientations, and longevity in teaching (part 2), Fournal of Teaching in Physical Education, 3(1), pp. 3-15.

LORTIE, D.C. (1975) School Teacher: A Sociological Study, (Chicago, II, University of Chicago Press).

MANOS, M.A. \& KASAMBIRA, K.P. (1998) Teach preparation programs and nontraditional students, Fournal of Teacher Education, 49(2), pp. 206-212.

METZLER, M.W. \& TJEERDSMA, B.L. (1998) PETE program assessment within a development, research, and improvement framework, Fournal of Teaching in Physical Education, 17, pp. 468-492.

O'BRYANT, C.P. (1996) Choosing physical education as a profession: stories of three AfricanAmerican women, unpublished doctoral dissertation, The Ohio State University.

PATTON, M. (1990) Qualitative Methods in Evaluation (Thousand Oaks, CA, Sage).

ROVEGNO, I. (1992) Learning to teach in a field-based methods course: the development of pedagogical content knowledge, Teaching and Teacher Education, 8(3), pp. 69-82.

SCHEMPP, P. (1989) Apprenticeship of observation and the development of PE teachers, in: T. TEMPLIN \& P. SCHEMPP (Eds) Socialization into Physical Education: Learning to Teach (Indianapolis, IN, Benchmark Press).

STROOT, S. \& WILLIAMSON, K. (1993) Issues and themes of socialization into physical education, Fournal of Teaching in Physical Education, 12, pp. 337-343.

TEMPLIN, T.J. \& SCHEMPP, P.G. (1989) Socialization into physical education: its heritage and hope, in: T. TEMPLIN \& P. SCHEMPP (Eds) Socialization into Physical Education pp. 1-11 (Indianapolis, IN, Benchmark Press).

TEMPLIN, T.J., WOODFORD, R. \& MULLING, G. (1982) On becoming a physical educator: occupational choice and the anticipatory socialization process, Quest, 34(2), pp. 119-133. 